\title{
The search for security in precarious times: non- traditional graduates perspectives on higher education and employment
}

Fergal Finnegan, Sandra Valadas, Jerry O’Neill, Antonio Fragoso \& Liliana Paulos

To cite this article: Fergal Finnegan, Sandra Valadas, Jerry O'Neill, Antonio Fragoso \& Liliana Paulos (2019) The search for security in precarious times: non-traditional graduates perspectives on higher education and employment, International Journal of Lifelong Education, 38:2, 157-170, DOI: $10.1080 / 02601370.2019 .1567613$

To link to this article: https://doi.org/10.1080/02601370.2019.1567613

Published online: 23 Jan 2019.

Submit your article to this journal $\sqsubset$

LII Article views: 130

View Crossmark data \lceil 


\title{
The search for security in precarious times: non-traditional graduates perspectives on higher education and employment
}

\author{
Fergal Finnegan ${ }^{a}$, Sandra Valadas $\mathbb{D}^{b}{ }^{\mathrm{b}}$, Jerry $\mathrm{O}^{\prime} \mathrm{Neill}^{\mathrm{c}}$, Antonio Fragoso ${ }^{\mathrm{b}}$ and Liliana Paulos
}

aDepartment of Adult and community Education, National University of Ireland Maynooth, Maynooth, Ireland; ${ }^{\mathrm{b} C I E O}$, Universidade do Algarve - Campus de Gambelas, Faro, Portugal; 'National University of Ireland Maynooth, Maynooth, Ireland

\begin{abstract}
This article explores non-traditional student and graduate views of the university in Ireland and Portugal as it relates to their expectations of, and experiences in, the labour market. The research is based on in-depth biographical interviews with 61 non-traditional students and graduates conducted longitudinally ( 85 interviews in total). The article contextualises the research in relation to the expansion of higher education internationally as well as national and EU policies aimed at supporting a 'knowledge-based economy'. It offers an overview of the meaning of precarity. It then outlines key empirical findings from the research related to student expectations of their degree and their postgraduation experience in the labour market. In particular, it explores the phenomenon of precarity amongst graduates how this is experienced and handled in various ways. Using a critical and egalitarian lens the overall aim of the research is to widen the focus of widening participation debates and explore how educational and institutional initiatives impact, or not, on wider social and employment inequalities.
\end{abstract}

\section{KEYWORDS}

Higher education; non-traditional students; equality; precarity; biographical methods

\section{Introduction}

In this paper, based on qualitative research in Portugal and Ireland, we explore 'non-traditional' higher education (HE) students and graduates' expectations and experiences of the labour market. The term 'non-traditional student' refers to groups of students who are under-represented in HE due to structural and institutional barriers. This includes people with disabilities, mature students, and students from working-class and particular ethnic backgrounds. Widening participation to $\mathrm{HE}$ has been the focus of research and policy for a long time but what happens to non-traditional students after they graduate still remains under-researched. Policymakers, embedded in a human capital perspective, assume that obtaining a degree will enhance career prospects and living conditions of non-traditional graduates, but there is a dearth of research that explores how true this is and almost no research which explores this based on students and graduates' perspectives. We sought to address this gap. The article foregrounds two key findings from the research which taken together are highly pertinent to widening participation debates: Most of the non-traditional students we met assumed a degree would lead to greater security but after graduation experienced a high level of precarity in the labour market.

We will first outline the social and policy context for the research, focusing on the expansion of HE, the promotion of the idea of the Knowledge-Based Economy (KBE) and the growth of credentialisation. We then discuss our understanding of precarity. Following this, we outline the 
methodological approach we have used in the research. The second half of the paper discusses the empirical findings based on biographical research with students and graduates. We detail how the university was viewed by most non-traditional students as a space of transition and learning which crucially they believed would contribute to their occupational security and well-being in the future. We then explore if these expectations were met based on the graduates' accounts of their experiences in the labour market and discuss how widespread precarity is amongst nontraditional graduates. These shared social conditions are worked through in varied ways by graduates though. The paper will illustrate how diverse adaptive strategies are located within differing 'horizons of expectation' - shaped by objective opportunities, the extent to which insecurity is 'embraced' and diverse temporal frames - through case studies. We conclude with some reflections on the findings for policy and research.

\section{'Mass' education, credentialisation and the knowledge economy}

One of the most obvious and significant trends in education over the past 40 years is its 'massification' at all levels. The expansion of HE has been particularly dramatic; the number of students enrolled in HE institutions across the world has doubled over the past 20 years (Brown, Lauder, \& Ashton, 2011). In Europe, this has largely occurred after the mid-1980s (Schofer \& Meyer, 2005) including in the two countries discussed in this article. In Ireland, in 1980, there were 15,000 third level students and today there are approximately 225,000 students in a country of 4 million people (Fleming, Finnegan, \& Loxley, 2017). In the Portuguese case, in the 1980s there were 81,000 people attending higher education and last year almost 357,000 were $\mathrm{HE}$ students (PORDATA, 2017).

It is argued that the expansion of education enhances the store of human capital (Becker, 1993) based on the belief that increased participation in education has multiple positive 'downstream' effects for society and education (Barro, 1991). Policymakers have developed these propositions into an elaborate socio-educational ideal and linked the expansion of $\mathrm{HE}$ to the emergence of the knowledge economy (EC, 2010; OECD, 1996; World Bank, 2002 etc.). As Jessop (2012, p. 57) notes, over the past 20 years this idea has been adopted by powerful transnational bodies such as the EU and most nation states in the global north; 'The knowledge-based economy has become the hegemonic representation or self-description of the economy as an emerging reality, an object of calculation, and object of governance in contemporary world society'.

A key claim of proponents of the KBE is that the world of work in highly industrialised OECD countries has undergone major structural changes in recent decades. It is posited that there has been a shift from an industrial society to a KBE driven by technological innovation and intensified international competition (Nilsson, 2017). This is linked to changes in the international division of labour and the emergence of new modes of organising work, associated with the globalisation of manufacturing, as well as the rise of service industries and increased job specialisation. Nation states and regions, it is argued, can only hope to maintain competitiveness and living standards if the governments invest in education that promotes innovation and productivity, especially in high-skilled work (Green, 2017).

These ideas underpin the reform of European HE that has been advanced through the Bologna process and the Lisbon Research Agenda (Keeling, 2006). Policymakers argue (EC (European Commission with EACEA/Eurydice), 2014) that tighter integration between labour markets and HE will improve economic competitiveness and enhance the employability of graduates. But it is important to note in relation to the findings detailed below that these are not just nostrums repeated in policy circles though; they are, as we shall see, beliefs that are widely held in society as a whole. The promise is that completing $\mathrm{HE}$ and obtaining higher qualifications provides a greater range of career opportunities and lead to individual upward social mobility (Alves, 2009; Mok \& Neubauer, 2016).

We now have in Europe the most qualified generation of young people in history and extraordinary, perhaps unprecedented, faith in education as a driver of social and economic 
progress amongst policymakers. In fact, the KBE model appears to be now so powerful that clear evidence of counter-tendencies is overlooked. Although graduates continue to retain some comparative advantage in terms of employment and income over non-graduates, research indicates that 'mass' education has led to credential inflation and increased competition for graduate positions as well as unemployment and underemployment, with many graduates finding employment in non-graduate positions (Brown et al; 2011; Burke, 2016; Purcell et al., 2012; Scurry \& Blenkinsopp, 2011; Tholen, 2014; Tomlison and Holmes, 2017).

\section{Widening participation, labour markets and persistent inequalities}

Despite these tensions and contradictions on a European (EC, 2014) and a national level (DES (Department of Education and Skills), 2011; DGEEC (Direção-Geral de Estatísticas da Educação e Ciência), 2017) faith in higher education appears to remain undimmed. Besides maintaining competitiveness and facilitating individual social mobility it is argued that HE can also overcome longstanding social and educational inequalities. In fact, all these aims are seen as commensurable and complementary. This is remarkable given that there is an extensive body of empirical work that indicates that higher education is characterised by deeply rooted inequalities of access, participation and outcomes linked to a social background (e.g. Attewell \& Newman, 2010; Shavit \& Blossfeld, 1993 inter alia). Furthermore, research suggests education is structured in a way that serves to advantage dominant groups and plays a vital role in reproducing inequalities (e.g. Attewell \& Newman, 2010; Bourdieu \& Passeron, 1977; Collins, 1979). Besides this, we also know that inequalities in wealth and income have become sharper in exactly the same period in which HE has expanded so dramatically (Sayer, 2015).

Yet, European policymakers continue to firmly believe equality can be advanced through participation in HE and now explicitly link employability, access and widening participation to each other (EC (European Commission with EACEA/Eurydice), 2014). However, we still know relatively little about how non-traditional graduates fare in labour markets. It is assumed that data on aggregate graduate destinations is sufficient and that widening access into HE addresses inequality inside and outside universities as a matter of course. For example, in Ireland, widening participation research has focused on pathways into university, participation levels and, more recently, retention, but very rarely looked at non-traditional graduate destinations (Fleming et al., 2017). In Portugal, while some researchers have examined transitions from secondary school into the university and, more recently, from the university into the labour market, most of the results have not looked at the trajectories of non-traditional students. The studies which do explore these questions indicate that non-traditional graduates are often at a disadvantage in the labour market because of their ethnicity, gender, social class, disability or age (Brown \& Hesketh, 2004; Burke, 2016).

\section{Precarity}

Our empirical research suggests that most non-traditional students believe strongly that HE will lead to greater security but are in fact encountering high levels of precarity after graduation. There is now a large and growing body of academic and activist literature on precarity which links the term to a very wide range of phenomena and conceptualises the meaning of precarity in multiple ways. It is beyond the remit of the current article to offer an exhaustive overview; instead, we offer an outline of how we understand the term.

Following Bourdieu (1998), we use the term precarity to denote the increased level of social vulnerability, insecurity and instability created by the long-term effects of neo-liberal globalisation. According to Standing (2009) the global deregulation of labour markets and the concomitant shift from welfare to 'workfare' in the world's wealthiest countries has been the central driver of precarity. Standing argues that guarantees from employers in terms of income, contracts, conditions as well as 
rights and public resources provided by the state, most notably those that linked employment and job security, have been removed. This has led to an 'explosion of atypical work arrangements far removed from the world of social welfare systems, union contracts, and long-term tenure with a single employer' that characterised employment in a 'Fordist' era (Ross, 2009, p. 5). The argument is that the intensification of market logic in advanced capitalism in the world of work, but also in previously de-commodified or non-commodified spheres of activity, including education, is leading to 'precaritisation' and a growing sense of insecurity.

However, this is a little too 'fuzzy' as a concept and we want to discuss four dimensions of precarity in a little more detail. First of all, a little more must be said about how large-scale research has linked precarity to contracts and conditions in employment. Put simply the rise of freelancing and other own account occupations, the use of fixed-term and zero-hour contracts, the increase of part-time work, causalisation through technology and the use of intermediary human resource agencies, as well as a rise in underemployment and the number of permanently jobless people, are viewed as evidence of a more general trend towards a more precarious society. Although this is especially common amongst younger workers, the disadvantaged and marginalised, it is argued that 'the logic of precarity pervades the entirety of society, squeezing the middle class out of decently paid, long-term jobs' (Foti, 2017, p. 9).

This brings us to the second important aspect of precarity: the demands for increased flexibility from employees, the lack of certainty about occupational paths and the fraying of social 'safety nets' have created widespread anxiety which has begun to permeate everyday life and culture (Berardi, 2015; Standing, 2009). It is even claimed that the disappearance of secure occupational identities, and a sense of the social purpose of work, has made it much harder to develop a secure social identity and even 'the corrosion of character' (Sennett, 1998). As biographical researchers, how such insecurity is perceived, storied and negotiated is of particular interest to us.

This is linked to, but distinct from, the third dimension of precarity. Some authors (e.g. Berardi, 2015; Standing, 2009 inter alia) connect this sense of insecurity to wider politics and a sense of powerlessness and social subordination (it is perhaps worth recalling that the word precarity has its origins in the plea and pray). In particular, precarity is characterised by increased individualisation in a variety of ways. As the ILO (2011, p. 27) have noted 'in the most general sense, precarious work is a mean for employers to shift risks and responsibilities on to workers. Part of this is undoubted because organised labour is weaker than it was a generation ago (Harvey, 2010). This is linked to a wider set of political changes characterised by a startling rise in inequality, the consolidation of power by elites (Sayer, 2015) and the acceleration of the speed of everyday life. All of this has occurred in a single generation and, as a result, it is argued that there is a widespread mood of political and cultural exhaustion (Berardi, 2015).

In summary, precarity has come into use to denote the insecurity and subordination that has come about as a consequence in changes in the nature of work and occupational structures, the unravelling of the welfare state and the increased mobility of capital. Precarity in life and labour is hardly a new phenomenon, and we need to be wary of romanticising the Fordist era; however, the rapid increase in levels of inequality, a shift in political conditions in which collective movements have less purchase and the sheer pace of change is creating new types of insecurities. Yet, it is the individual, the 'reponsibilised subject', is tasked with resolving social problems and overcoming risks on their own. This cumulatively has created a political mood or even conjuncture marked by a loss of collective narratives, increased anxiety and even, a sense of uncertain futures and even futurelessness (the fourth dimension of precarity).

\section{Precarity in a time of crisis}

Our research was conducted in the wake of 'the Great Recession' in a period of crisis and austerity, which was particularly sharp in Ireland and Portugal and has intensified precarity in these countries. 
In Ireland, for instance, neo-liberalism, albeit with distinctive Irish characteristics, has informed socio-economic policies since the late 1980s. Ireland is famous for its 'light touch' regulation of business and low corporate taxation. Consequently, it is one of the most globalised economies in the world, is highly financialised and largely dependent on foreign direct investment (McCabe, 2011). Before, during and after the boom period in the 1990s, Ireland has been marked by high levels of social inequality (Kirby, 2010). It is especially pertinent that there has been a massive increase in the 'indirect labour', 'knowledge work' in the labour market accompanied by occupational polarisation with growth in professional and technical work and routine non-manual work alongside a diminution of well-paid, often unionised, manufacturing jobs (Breathnach, 2007).

Despite these trends and the move to a highly flexible and polarised labour market, 'precarity' was not widely discussed as an issue in Ireland before the 'Great Recession'. Part of the reason is that this was easy to overlook when there was a high rate of employment, rising levels of income and the state maintained a consensual 'social partnership' model of governance. The crisis and bank bailout (which was commonly estimated at costing over 64 billion euro) and the government implemented austerity measures which were overseen and partially devised by the Troika (IMF-European Commission-European Central Bank) changed things radically. Unemployment grew by $10 \%$ and the workforce shrunk by $14 \%$, wages collapsed and fiscal control and budgetary restraint became the watchwords of the day (Taft, 2013; Walsh, 2016); competitiveness could only be restored, the state and the Troika claimed, by austerity, increased flexibility from employees, especially in the public sector, and labour activation measures.

There has been a significant rise in temporary employment contracts for younger workers and the crisis also led, in part through state-sponsored internships, to a significant increase in underemployment (Taft, 2013). A recent study (Wickham \& Bobek, 2016) also documents a much greater level of 'enforced flexibility' - that is workers having to accommodate increased demands in the intensity and length of their work - based on real and perceived insecurities in the labour market. The effect of the crisis on employment prospects and heightened insecurity in income, jobs and welfare has compounded existing inequalities and badly hit migrants, youth and the working class. The stabilisation and recovery of the economy have not significantly lessened inequality.

In Portugal, similar to what happened in Ireland, in the 1980s, Atlantic neo-liberalism was embraced with aggressive enthusiasm by the government (Finn, 2017). Portugal became the EU's leader in privatisation. In all, more than a thousand enterprises were sold off to 44 corporations, leading to a greater concentration of capital than under the dictatorship (Louçã, Teixeira Lopes, \& Costa, 2014). In recent decades, there have been constant labour market reforms, leading to more precarious working conditions, low-paid jobs and lack of security (Rodrigues, Figueiras, \& Junqueira, 2016; Valadas, 2016). As in Ireland, the Portuguese government came under the close supervision of three international agencies (IMF, EC, ECB), which had a significant impact on everyday life. Portugal was badly hit by the global financial crisis and suffered unprecedented job losses (OECD, 2017). Total employment fell by $767000(-15 \%)$ between mid-2008 and the beginning of 2013; in the period of crisis, unemployment went from $7.6 \%$ in 2008 to $16.2 \%$ in 2013 (PORDATA, 2017). The declining situation in terms of the labour market performance is accompanied by the reconfiguration/dismantling of the welfare system (Hespanha \& Portugal, 2015).

According to Valadas (2016) hiring workers under precarious labour contracts is not novel in Portugal, but in nowadays old forms of precarity (e.g. informal work) coexist with new forms of precarious work. Inequalities are growing significantly, and precarity is now an objective problem in Portugal, similar to what happens in Ireland, with potentially destabilizing levels of youth unemployment and underemployment, notably the increase in non-standard employment (currently $22.3 \%$ of the population is on temporary contracts (PORDATA, 2017).

\section{Methodology: a critical, egalitarian use of biographical methods}

This research was conducted in the context of a European project (EMPLOY) ${ }^{1}$ involving six partners from across Europe (UK, Sweden, Spain, Ireland, Poland and Portugal) which examined student, staff, 
employer views on employability as well as the experience of non-traditional graduates in the labour market. The EMPLOY project sought to investigate these issues empirically with a particular interest in the agency and perceptions of students and graduates. Specifically, we used biographical interviews to explore students' experience, as well as their career expectations and graduate trajectories.

Biographical interviews are open, interviewee led, highly detailed accounts of life experience. Our approach draws on Merrill and West (2009) collaborative and relational methodology for interviewing and is also informed by the idea that 'Biography itself has become a field of learning in which transitions have to be anticipated and coped with, and where personal identity is liable to be the result of long and protracted learning processes' (Alheit, 1994, p. 285). We are especially interested in how experiences and choices are situated in a specific cultural and political context. Framed in this way biographical accounts afford insight into the complex interplay between structure and agency and allow researchers to trace connections between people self-perceptions and wider trends and tendencies. We think this sort of biographical approach used longitudinally is especially useful in understanding transitions between education and work.

A central aim of our research has been to attempt to understand HE in relation to the labour market from the perspective of students and graduates. This inquiry is underpinned by a multidimensional conception of equality which is used to explore how more equal access to cultural and economic resources and valued social practices can contribute to human development (Baker, Lynch, Cantillon, \& Walsh, 2009). From this perspective biographical approaches can be used to offer 'focused points in human experience that can teach something about a more general problem of denial and frustration built into the social order' (Sennett \& Cobb, 1977, p. 45), as well as illuminate how everyday agency can circumvent or overcome structural barriers.

\section{Cohorts}

In Ireland, we met with 20 final year students and 10 graduates (who finished their first degrees between 4 and 19 years ago). Students were recruited through an email to all final year students in the university and through the Alumni association. We did follow up interviews with 14 people a year after they graduated. The participants all attended the same non-elite university and were drawn from all three faculties of the university (social science, arts and humanities and science). Two-thirds of the participants were women, three quarters were mature students and a small majority were working class (18 of 30 ). We only had a small number of students with disabilities or who were from minority ethnic communities.

In Portugal, 31 mature students and graduates of various ages were interviewed, all from a University in the south of the country. The majority were women (18). Follow-up interviews were performed with 10 participants a year after graduation. Students ranged from different scientific areas, such as Social Education, Clinical Analyses, Communication Design, Marine Biology, Agronomy or Psychology.

\section{Analysis and sensitising concepts}

Taking a critical realist approach (Bhaskar, 1979; Sayer, 1992) we sought to work between grounded empirical research and systematic theoretical investigation of the socio-historical and institutional context. Emerging categories and subcategories were identified in the interview transcripts (Kondracki \& Wellman, 2002) using a broadly inductive approach. Alongside this, based on prior field and desk research, we also selected several 'sensitising concepts' (Blumer, 1954) at the beginning of the project. These concepts were used to suggest possible directions for analysis and were exploratory, rather than definitive. One of these concepts was precarity: Initially, we explored various interpretations of precarity and then sketched out our own understanding of the idea. This review convinced us that it may have explanatory potential, but we remained tentative about its value until much later after testing it through, and against, the data. 
An analysis in the EMPLOY project was done separately on a national level first, and each team in the project then presented their findings to the network. Over three years it became apparent that there were significant overlaps in the findings of the Irish and Portuguese teams linked to the ongoing impact of the Great Recession on education and society. To explore this further we embarked on bi-national comparative analysis. This confirmed the importance of precarity across the two countries and striking commonalities between them, not least just how generalised this has become. But as we moved into more fine-grained analysis it became apparent that precarity was been experienced and responded to in various ways by non-traditional graduates and that there were important differences between graduates based on objective conditions, perceptions of insecurity and future expectations. These differences cannot be straightforwardlyexplained as the 'effect' of a specific non-traditional status national context.

\section{Findings: HE and the search for good work and security in precarious times}

In this section, we detail briefly how participants viewed HE, especially in relation to career paths and security before graduation. Taking account of these expectations is necessary to make sense of what transpired after graduation. This will be used to frame the discussion of the most prominent theme is the research-precarity. We will give an overview of the extent, sources and intensity of precarity in the participants post-graduation stories in Ireland and Portugal. Following this through five case studies, we will seek to illuminate how precarious times are handled on a biographical level and will argue that the experience of precarity is highly differentiated and there are sub-cohorts with distinct and identifiable horizons of expectations.

\section{The value of HE in a period of flux}

The theme of change - linked to a range of things such as family, education, community life, gender roles and work - was especially prominent in the interviews. In both Ireland and Portugal, rapid socio-economic and cultural change over a generation has led to the 'detraditionalisation' of the life course where 'standard' expectations no longer hold, and the phases and trajectories of life have become more unpredictable and less linear (Alheit \& Dausien, 2000). This phenomenon is strongly linked to changes in work and the fragmentation of career paths (Baruch., 2001), but cannot be ascribed solely to occupational change.

It seems that social flux has altered the practical and symbolic value of $H E$ in Ireland and Portugal. HE offers a defined institutional space which allows space for planning, development and even a refuge from insecurity. Most of the students we met, both young and mature, saw HE in this way. Many people - especially working-class students - spoke about extended experiences of insecurity in their own and their families' working lives. Of getting by, doing bits and pieces, of managing on very tight finances and, for some, of unwanted periods on social welfare. These life experiences make the promise of security through HE very attractive. Beside this, most of the mature students we met had been knocked off a career and/or life path by the economic crisis or other major life events. A smaller group had moved away from a specific career or lifestyle that they felt constrained by in some way. The significant thing is that is the vast majority of cases $\mathrm{HE}$ was seen as the path to more solid ground and as an opportunity to accrue cultural and social capital.

As a consequence, people expended enormous time and effort getting into and through university in large part because they believed that a degree would lead to, or at the very least would be necessary to get, a 'proper job' after graduation. This is understood in various ways 'decent' money, a job which fits personal values and interests, a position which offers status, autonomy and respect, and opportunities for personal and social development (see also Purcell et al., 2012). The search for 'good work', for the majority of the people we spoke with, was also closely linked to a desire for security. Again, this is discussed in diverse terms - permanency, 
predictable hours and secure income, having a pension and so forth. But security often means something more as well; it touches also on existential questions linked to identity and social recognition through employment, the desire to flourish and to be someone in your own and other people's eyes.

Nevertheless, it is important to say that security was not the sole focus of the graduates. The interviewees also told us how much they appreciated time to think, intellectual stimulation, and becoming more critically aware. HE was seen as a type of transitional space of both personal and professional formation, and it was widely held by the people we met that a degree will open doors that were previously closed to them. By passing through transitional space it is believed, or at least hoped, that precarity, inequality and/or the worst effects of crisis would become things of the past. But were Irish and Portuguese graduates' expectations met?

\section{Graduate experiences in the labour market}

In objective outcomes, there were significant differences between national contexts: Only a small number of Irish graduates were unemployed, but a quarter of the Portuguese graduates were without work. Many interviewees in both places had moved into more 'skilled' and professional work, but a lot of graduates were working for lower salaries than might be expected, especially in Portugal. Lengthy transition periods after graduation was the norm, as was a certain haziness about their 'final' destinations. There was also a strong awareness of credentialisation amongst the students: As Chloe, a young working-class Irish graduate, put it 'you need a degree to work in a supermarket these days'. For that reason, many graduates went into the postgraduate study after their primary degree or were actively considering doing so in the future. Only a minority of those interviewed in Ireland and Portugal (less than a sixth of the people we spoke with) were in permanent positions after graduation and nearly all those with permanent jobs were in the civil service. Overall, it is remarkable just how general concerns about insecurity and precarity were (just under two-thirds of the participants in Ireland and the overwhelming majority of interviewees in Portugal). Simply put graduates were not in the type of job or the type of contractual situation they hoped, or expected, to be in after university. It is striking that of the 10 follow-up interviews conducted in Portugal, not a single worker thought their professional life has improved.

To return to the discussion of precarity in the first half of the paper the data suggests that occupational insecurity is indeed creating widespread anxiety and concern (the first two dimensions). It was particularly striking that in both Ireland and Portugal, success or failure to arrive at the desired destination after graduation was seen, wholly or largely, as an individual responsibility (the third dimension of precarity). However, while the majority of the graduates sought security and found themselves in precarious conditions, how insecurity and precarity are experienced, internalised, spoken about, and acted upon varied significantly. What emerged from the interviews were highly diverse 'biographical constructions [which] are a result of ongoing coping processes with social reality' (Alheit \& Dausien, 2000, p. 5). These constructions are not autopoietic - there are a strong class, age and gender dimensions that constrain and enable biographical action - but neither are completely socially determined. In exploring the range of responses, it became clear that how precarity is interpreted depends on varied adaptive strategies linked to: (1) objective opportunities and resources; but also (2) the degree to which insecurity is 'normalised' or even embraced; and (3) varying notions of the future.

This creates distinct and varying 'horizons of expectations', as a result, that precarity is internalised in different ways over time - as proximate or distant to the self. This complicates the fourth dimension of precarity (uncertain futures/futurelessness) which is less 'flat' a phenomenon than a good deal of the literature on precarity suggests. Concretely, many graduates, usually young, feel their current circumstances are not ideal but 'good enough' for the time being. For others, precarious conditions have become the norm, a professional trajectory 
that Alves (2009) calls 'stability in precarity' - people whose work over the long consists of multiple short-term projects (this may be either resented or celebrated). They believe that a job for life does not exist anymore and say that degrees now have limited value. We also met graduates who are in a state of constant tension because they do not have the career and life they desire. Low pay, a lack of contractual security and disappointed expectations feed a deep sense of insecurity and, in some cases, even led some interviewees to postpone or abandon the idea of having children. When insecurity in employment, income and career trajectories are combined with debt and the binds and responsibilities of care, the impact can be truly devastating.

We want to illustrate this range of conditions experienced by non-traditional graduates - and the varied responses and impact of those conditions - through five brief case-studies.

\section{Chloe: still in transition, but for how long?}

Chloe is an Irish 21-year-old social science student. She is from a working class, rural background, and she speaks passionately about this region and her family's lives, saying it is 'overlooked', 'ignored' and 'forgotten'. This family history directly informed her of the desire to find a more secure type of work for herself after college. When we first met, she said that after college: 'I know it's going to take a few more years of living off beans on toast, you know. It's not going to be easy'. She imagines though that after postgraduate study and perhaps an internship, she will end up in a government department or NGO. She pictures herself with a desk, with books on the shelves 'helping other people understand' issues of inequality. Her job is imagined as less frantic than the part-time catering job she had at the time of the first interview, more secure and less physically demanding than her parents' occupations and providing her with the opportunity to help other 'overlooked' places. While she was acutely aware that she did not have the same resources or social networks as middle-class students, she was very positive in her final year that she would eventually find the position she wanted.

But Chloe was less sanguine a year after graduating. She is doing a Masters, which she can only afford because of a small inheritance and by working full-time. The job has relieved some of the financial pressure she was under previously, but in some respects, she feels more constrained now and certainly more vulnerable. She does shift work which is highly stressful, sometimes even dangerous. The private company that employs her, and is contracted by the state for its services, is desperate for workers, as people burn out so quickly. Her employers may even offer her a permanent contract in time, but the wages and conditions are not great and not typical of a 'graduate job'. She wants something else but: 'how to get to where you want to be? It is so competitive, so many criteria. I have seen the lack of jobs. It is kind of disheartening as there is nothing out there for me. Maybe in ten years?'

\section{Vera: reluctant acceptance of precarity}

Vera is 32 years old, and she is a Psychology graduate from Portugal. In the past, she had precarious jobs over a long period of her life. Today she moves in different milieus: She is active as a trainer in psychology and as a consultant in Digital Marketing.

Vera thinks that the notion of having a job for life has ended, and the important thing is the ability to work in different areas, rather than just in one. The range of activities that she can perform at allows Vera to be an independent worker. Objectively, Vera's situation is precarious, with a very limited safety or security and her salary is low. She says:

"I have always had work... But I cannot avoid the constant question "what if in the end of the month I have no salary?" But I must not think like that. I prefer instead to be positive and to think that I never been without work." 
Her reputation and the social professional networks she has built assures a constant flow of clients, which gives her the feeling of having achieved relative stability. Nevertheless, she recognises the difficulties: She handles her finances with care so that she can keep a safeguard in the case of some illness - after all, she does not have the same social protection as other workers do.

Vera's case illustrates the deterioration of graduate employment and her frustration is clear:

"In Portugal, I can get a job, but it is always on the basis of survival. And when we have work experience and we have invested many years and money in higher education, I think that this kind of situation is unfair. [...] I do not care if I earn $500 €$ working on a supermarket; but I care if I earn $500 €$ on a job that demands a degree. Employers do not remunerate you for the level of responsibility [..] and I felt this when I was working in health. We have to take life and death decisions, we put our lives at risk [..and] I have earned 600 $€$ a month.”

\section{David: coping with extended precarity and an uncertain future}

David is in his 40s, a proud family man from Ireland who has completed his degree 8 years ago, and the next year went to do a postgraduate teaching qualification. This was an enormous achievement, given the fact that he was edged out of school early and came from what he called 'a deprived background, deprived of education and knowledge, deprived of capability and opportunities'.

He immediately started looking for a job after qualifying. He found work 'subbing' (temporary teaching posts where you stand in for permanent member of staff. Davidbuilt his CV by paying privately for professional development courses and involving himself in an extracurricular activity at the school. He cultivated social networks and developed an in-depth knowledge of how to approach interviews. When nothing secure became available in his second year he decided, very reluctantly, to teach abroad. This put pressure on his family and he came back the following year determined to find something closer to home. This proved very difficult. Austerity policies meant there was a hiring freeze, and the expansion of $\mathrm{HE}$ and the arrival of private teaching colleges in Ireland have made educational qualifications much more common, especially in Arts subjects.

David found himself in a very insecure situation at work, where he was highly reliant on the assessment of management of his performance. Most of his work, especially with vulnerable students, was successful. But despite repeated applications and interviews, he has now been working for over five years in a series of highly precarious teaching posts. He is currently teaching in a school where he has no security at all and has to commute several hours a day to reach.

Despite having a highly optimistic outlook there is an understandable sense of frustration, almost anguish, when David tells me: 'I have done everything I can to be, try and make myself invaluable', 'trying to feckin please everybody'. His time, and even his future, is not entirely in his hands. Waiting, watching, upskilling and constantly trying to perform comes at a cost to how he feels about himself - and he became depressed and anxious. This permeated into his family life, which he has always regarded as his haven, his 'luck' and comfort in life. He earns less than he did before as a driver, and the costs of travel have to be carefully budgeted for. Although highly agentic, well qualified, committed to his subject and passionate about connecting with disadvantaged school-goers, he cannot see a clear way forward. He says he feels his age and has put effort into looking fitter, but still thinks this and some of his choices now mean he may never get a permanent post. He talks of moving abroad again but feels, and this is seen almost entirely as his own responsibility, that he is likely to remain precarious for the foreseeable future.

\section{Grace: surfing the waves}

Grace is Irish and in her mid-30s. Not only she accepts change and contingency in her working life, but she embraces it. From a working-class background, she decided at 12 she wanted to be 
a scientist. This hope seemed somehow unrealisable, given her family, community and school's expectations, but through 'luck' she got into college. Despite her self-effacing manner, it is clear from her description of events that she is highly determined and adept at forging connections with people. She was very active in societies and student politics and learnt how to be an effective communicator. Grace even described talking to a new professor into giving her job: "I literally ran over there on my break and I said 'Hey you know, I am looking to do a Master or a $\mathrm{PhD}$ or whatever [..]. Give me a job basically'. This was successful but, and again this is characteristic, she abandoned the $\mathrm{PhD}$ when it proved unsatisfying. Grace does not discuss this with any regret - it was just as the right choice under the circumstances.

She has brought this capacity to adapt, as well as her self-presentation and social networking skills, into the labour market. She discusses moving on and leaping between jobs: 'I will work in something until I get bored or you know just feel it like time to move on'. The economic crisis did create temporary difficulties, but she got through this: 'I am always doing something' and 'I am a great believer in just trying things and if it does not work drop it'. In fact, Grace abandoned a permanent job when a new boss who she did not like came into the organisation.

Although she is not on a permanent contract, it should be noted, she is not precarious financially or constrained in her choices. She is currently a highly paid consultant in information technology. Grace seems to thrive on a flexible occupational identity and does not know, or need to know, what job she will be doing in the future. Grace comes back to the notion of the inevitability of flux quite often: 'things are changing so fast' she says and thinks this has to be accepted and even celebrated.

\section{Laura: the cost of precarity}

Laura is Portuguese, 31 years old, and she is a graduate in Social Work. She comes from a working-class background and had a precarious working and personal life. Her parents wanted her to abandon school and start to work. In HE she continued her lonely struggle - her parents never supported her or understood her efforts. She took on a series of low-skilled jobs, both parttime and full-time, to get by.

After graduation, she did a professional internship, but no job materialised afterwards. Instead, she found herself on a series of temporary contracts punctuated by short periods of unemployment. Her bosses always thought she worked well but that did not seem to make a difference. The fact that she could not understand why this was happening made it harder to endure. During the final year of her masters, she suffered a nervous breakdown and a subsequent depression which has not entirely passed. Laura manages to work, but it is difficult to endure the feelings of uncertainty and anxiety brought on by the precarity of her professional situation. Uncertainties about the future are accumulating, and she feels intense fatigue due to her efforts to prove herself to employers.

These five case studies have been selected to illustrate various horizons of expectation but of course, they are not equally prevalent. The most typical is Ireland is Chloe's story (disappointed but still hopeful of overcoming insecurity in the future) but in Portugal Vera's story is more common where it is widely believed work and society will remain precarious. In both countries amongst mature graduates who have experienced a longer period of precarity, such as David, this is more sharply felt, and this is even true for graduates who come from a middle-class background. The least common in either place - where a highly adaptive disposition and objective opportunities allow 'surfing'.

\section{Concluding reflections}

The literature explored in the first half of the article indicates that specific economic and political conditions linked to neo-liberalism have made the flux of modern life not just unstable but insecure over extended periods and into the future. Our research suggests this is indeed the case. 
Non-traditional graduates, from all class backgrounds, both genders and all ages, are encountering precarity and this typically lasts for several years. Post-crisis precarity has become generalised. There is often the feeling of having won the 'first round' in HE, but not knowing if they have the strengths and resources to win the 'second round'. This makes it difficult to build coherent occupational, or even for some biographical, identities. For graduates who are older, this can be especially challenging. Regardless of how this is perceived and biographically constructed the individualisation of responsibility is ubiquitous.

But precarity is a highly variegated phenomenon and in both countries, the impact and intensity of precarity differ greatly between occupations and sectors. The research indicates that objective opportunities and previously accrued resources in highly competitive, segmented labour markets remain the pre-eminent factors in how straightforward and 'seamless' graduate transitions are.

Our research indicates how change is framed and interpreted by individuals deserves attention. For example, what is shared by the surfers, and this content with being 'still in transition' is a belief that they are in a position which has a medium-term future. But when desired, or anticipated, futures are seen as rapidly receding into the distance, it is far more difficult to feel you are flourishing in work and life. Long periods of uncertainty and being forced to abandon cherished hopes affects people profoundly on an emotional, personal and social level.

HE has become a social space with many layers. Non-traditional graduates typically envisage it as a meritocratic space with clear entry points to good work and security. It serves as a refuge from unemployment, a space for intellectual development and identity work, even for recovery from difficult personal experiences. As we have seen the idea that HE will lead to upward mobility and security for such students remains common in popular and policy narratives. This fuelled students' determination and their 'will to learn'. But the accounts we have collected challenge the idea of seamless, frictionless transitions from $\mathrm{HE}$ into the labour market imagined by KBE proponents. Massification, credentialism and changes in labour markets have clearly created new tensions and contradictions in $\mathrm{HE}$ which are particularly important for understanding widening participation. As a result, we need to carefully consider whether a HE degree offers a credible route to either upward mobility or greater social equality. In a precarious era can HE policymakers, management and staff really continue to encourage such hopes? Our study indicates that constricted opportunities in employment and dwindling public resources in a precarious era make the promise of upward mobility and greater equality through widening participation a highly questionable proposition.

\section{Note}

1. The EMPLOY project is an Erasmus + funded project 2014-1-UK01-KA203-001842-TP.

\section{Disclosure statement}

No potential conflict of interest was reported by the authors.

\section{Funding}

This work was supported by the Foundation for Science and Technology (FCT) (Portugal) [project UID/SOC/ 04020/2013,]; EU Erasmus + EMPLOY [2014-1-UK01-KA203-001842-TP]; PhD internship Portugal [SFRH/BD/ 132068/201]; Foundation for Science and Technology Portugal (FCT), project UID/SOC/04020/2013 and PhD internship Portugal SFRH/BD/132068/2017. 


\section{Notes on contributors}

Fergal Finnegan is an adult educator from Dublin and is a lecturer with the Department of Adult and Community Education at Maynooth University, Ireland. His main research interests are equality, higher education, social class, biographical methods and transformative learning

Sandra Valadas is Assistant Professor at the University of Algarve (Faro, Portugal). She has experience in national and international projects. Her actual research interests include transitions to the labour market, employability and higher education, learning and teaching in higher education, elderly and transitions to retirement.

Jerry O'Neill is a lecturer with the Department of Adult and Community Education at Maynooth University, Ireland. He returned to higher education as a mature student in the late 1990s and has a keen interest in reflexive practice and research and the impact of precarity on adult educator development and professionality.

Antonio Fragoso is Associate Professor at the University of Algarve (Portugal). His research interest include adult education, community education and development; non-traditional students in higher education; and education and learning of older adults.

Liliana Paulos is a PhD student in Educational Sciences at the University of Minho. Her research interests include Higher Education, Transitions to the labour market, Identity, Employability and employment.

\section{ORCID}

Sandra Valadas (D) http://orcid.org/0000-0002-0531-8064

\section{References}

Alheit, P. (1994). The "biographical question" as a challenge to adult education. International Review of Education/ Internationale Zeitschrift für Erziehungswissenschaft/Revue internationale l'éducation, 40(3), 283-298.

Alheit, P., \& Dausien, B. (2000). Biographicity as a basic resource of lifelong learning. In P. Alheit, E. Kammler, R. Taylor, \& H. S. Olesen (Eds.), Lifelong learning inside and outside schools: Collected papers of the European conference on lifelong learning (pp. 400-422). Roskilde: Roskilde University.

Alves, N. (2009). Inserção profissional e formas identitárias. Lisboa: EDUCA.

Attewell, P. A., \& Newman, K. S. (2010). Growing gaps: Educational inequality around the world. New York: Oxford University Press.

Baker, J., Lynch, K., Cantillon, S., \& Walsh, J. (2009). Equality: From theory to action (2nd ed.). Basingstoke: Palgrave Macmillan.

Barro, R. (1991). Economic growth in a cross section of countries. The Quarterly Journal of Economics, 106(2), 407-443.

Baruch., Y. (2001). Employability: A substitute for loyalty? Human Resource Development International, 4(4), 543-566.

Becker, G. S. (1993). Human capital: A theoretical and empirical analysis, with special reference to education (3rd ed.). Chicago: The University of Chicago Press.

Berardi, F. (2015). Heroes: Mass murder and suicide. London: Verso.

Bhaskar, R. (1979). The possibility of naturalism: A philosophical critique of the contemporary human sciences. Atlantic Highlands, NJ: Humanities Press.

Blumer, H. (1954). What is wrong with social theory? American Sociological Review, 18, 3-10.

Bourdieu, P. (1998). Acts of resistance: Against the tyranny of the market. New York: The New Press.

Bourdieu, P., \& Passeron, J. C. (1977). Reproduction in education, society and culture. London: Sage.

Breathnach, P. (2007). Occupational change and social polarisation in Ireland: Further evidence. Irish Journal of Sociology, 16(1), 22-42.

Brown, P., \& Hesketh, A. (2004). The mismanagement of talent: Employability and jobs in the knowledge-based economy. Oxford: Oxford University Press.

Brown, P., Lauder, H., \& Ashton, D. (2011). The global auction: The broken promises of education, jobs, and incomes. New York: Oxford University Press.

Burke, C. (2016). Culture, capitals and graduate futures. London: Routledge.

Collins, R. (1979). The credential society: A historical sociology of education and stratification. New York: Academic Press.

DES (Department of Education and Skills). (2011). National strategy for higher education to 2030: Report of the strategy group. Dublin: DES. 
DGEEC (Direção-Geral de Estatísticas da Educação e Ciência). (2017). Sistema de consulta de informação e dos indicadores gerais da educação. Lisboa: DGEEC, MEC.

EC (European Commission). (2010). Communication from the Commission Europe 2020: A strategy for smart, sustainable and inclusive growth. Brussels: EC

EC (European Commission with EACEA/Eurydice). (2014). Modernisation of higher education in Europe: Access, retention and employability. Luxembourg: Publications Office of the European Union.

Finn, D. (2017). Editorial: Luso-anomalies. New Left Review, 106, 5-35.

Fleming, T., Finnegan, F., \& Loxley, A. (2017). Access and participation in Irish higher education. London: Palgrave Macmillan.

Foti, A. (2017). A general theory of precarity. Amsterdam: Institute of Network Cultures.

Green, A. (2017). The crisis for young people: Generational inequalities in education, work, housing and welfare. Switzerland: Palgrave Macmillan.

Harvey, D. (2010). The enigma of capital and the crises of capitalism. London: Profile.

Hespanha, P., \& Portugal, S. (2015). Welfare cuts and insecurity under the rule of austerity: The impact of the crisis on Portuguese social services. Oñati Socio-Legal Series, 5(4), 1110-1132.

ILO. (2011). Policies and regulations to combat precarious employment. Geneva: Author.

Jessop, B. (2012). A cultural political economy of competitiveness and its implications for higher education. In D. W. Livingstone \& D. Guile (Eds.), The knowledge economy and lifelong learning: A critical reader (pp. 57-83). Rotterdam: SENSE.

Keeling, R. (2006). The bologna process and the Lisbon research agenda: The European commission's expanding role in higher education discourse. European Journal of Education, 41(2), 203-223.

Kirby, P. (2010). The Celtic Tiger in collapse: Explaining the weaknesses of the Irish model (2nd ed.). Basingstoke: Palgrave Macmillan.

Kondracki, N. L., \& Wellman, N. S. (2002). Content analysis: Review of methods and their applications in nutrition education. Journal of Nutrition Education and Behavior, 34, 224-230.

Louçã, F., Teixeira Lopes, J., \& Costa, J. (2014). Os Burgueses (pp. 52-3, 508-9). Lisbon: Bertrand.

McCabe, C. (2011). Sins of the fathers: Tracing the decisions that shaped the Irish economy. Dublin: History Press.

Merrill, B., \& West, L. (2009). Using biographical methods in social research. Los Angeles: SAGE.

Mok, K. A., \& Neubauer, D. (2016). Higher education governance in crisis: A critical reflection on the massification of higher education, graduate employment and social mobility. Journal of Education and Work, 29(1), 1-12.

Nilsson, S. (2017). Employability, employment and the establishment of higher education graduates in the labour market. In M. Tomlinson \& L. Holmes (Eds.), Graduate employability in context (pp. 65-86). London: Palgrave Macmillan.

OECD. (1996). Knowledge based economy. Paris: Author.

OECD. (2017). Education at a Glance 2017: OECD Indicators. Paris: OECD Publishing. doi:10.1787/eag-2017-en

PORDATA. (2017). Retrato de Portugal. Resumo de indicadores da sociedade portuguesa contemporânea desde 1960 até ao último ano disponível. Lisboa: Fundação Francisco Manuel dos Santos.

Purcell, K., Elias, P., Atfield, G., Behle, H., Ellison, R., Luchinskaya, D., .. Tzanakou, C. (2012). Futuretrack: Transitions into employment, further study and other outcomes. Warwick: HECSU.

Rodrigues, C. F., Figueiras, R., \& Junqueira, V. (Coord.). (2016). Desigualdade do rendimento e pobreza em Portugal. As consequências sociais do programa de ajustamento. Lisboa: Fundação Francisco Manuel dos Santos.

Ross, A. (2009). Nice work if you can get it: Life and labor in precarious times. New York: NYU Press.

Sayer, A. (2015). Why we can't afford the rich. Bristol: Policy Press.

Sayer, R. A. (1992). Method in social science: A realist approach (2nd ed.). London: Routledge.

Schofer, E., \& Meyer, J. W. (2005). The world-wide expansion of higher education in the twentieth century. American Sociological Review, 70, 898-920.

Scurry, T., \& Blenkinsopp, J. (2011). Under-employment among recent graduates: A review of the literature. Personnel Review, 40(5), 643-659.

Sennett, R. (1998). The corrosion of character: The personal consequences of work in the new capitalism. New York: Norton. Sennett, R., \& Cobb, J. (1977). The hidden injuries of class. Cambridge: Cambridge University Press.

Shavit, Y., \& Blossfeld, H.-P. (1993). Persistent inequality: Changing educational attainment in thirteen countries. Boulder, CO: Westview Press.

Standing, G. (2009). Work after globalization: Building occupational citizenship. Cheltenham: Edward Elgar.

Taft, M. (2013). The class impact of the recession. Irish Marxist Review, 2(6), 1-16.

Tholen, G. (2014). The changing nature of the graduate labour market. New York: Palgrave Macmillan.

Tomlinson, M., \& Holmes, L. (Eds.) (2017). Graduate Employability in Context. London, UK: Palgrave, macmillan

Valadas, C. (2016). Structural unemployment and precarious work in a depressed labour market. Old and new trends in a southern European country. Organizações e Trabalho, 2014(41-42), 27-37.

Walsh, F. (2016). Labour market measures Ireland 2008-13: The crisis and beyond. Geneva: ILO.

Wickham, J., \& Bobek, A. (2016). Enforced flexibility? Working in Ireland today. Dublin: TASC.

World Bank. (2002). Constructing knowledge societies: New challenges for tertiary education. Washington, DC.: Education Group, Human Development Network. 